\title{
Exploring Acehnese EFL College Students' Perceptions on Collaborative Writing
}

\author{
Zulfikar $^{1}$, Cut Tarri Aulia ${ }^{2}$ \\ ${ }^{1}$ STAIN Mandailing Natal \\ e-mail: zulfikar@stain-madina.ac.id \\ ${ }^{2}$ UIN Ar-Raniry Banda Aceh \\ e-mail: cuttarri205@gmail.com

\begin{tabular}{ccc}
\hline Diterima & Direvisi & Disetujui \\
$06-07-2020$ & $26-08-2020$ & $03-09-2020$ \\
\hline
\end{tabular}

\begin{abstract}
Applying collaborative approaches in teaching writing has been shown to have a myriad of advantages. Most of the studies on collaborative writing in language teaching, however, have focused on second language rather than foreign language contexts. This study investigated perceptions of Acehnese EFL college students toward the implementation of collaborative writing in their EFL classrooms at Ar-Raniry State Islamic University, Banda Aceh, Indonesia. The general design of the research was qualitative in nature since the study used narrative inquiry as the research instrument and emphasized on each participant's learning experiences with collaborative writing strategy. In order to understand the participants' perceptions of collaborative learning, the researcher observed, took notes and recorded each of their interview responses. The overall results revealed that collaborative writing was perceived as beneficial for not only improving accuracy and clarity of the EFL students' writing, but also providing the opportunity for them to pool their ideas, reduce their apprehension, and increase their self-confidence. Results also showed that the EFL students believed that collaborative project writing was not always feasible due to their different writing style, social loafing, as well as time pressure. These findings could function as important intellectual resources for more effective collaborative writing implementation. The study concludes with recommendations for further pedagogical explorations on different aspects of collaborative writing in EFL context in the future.
\end{abstract}

Key words: students' perceptions, collaborative writing, writing classrooms

Abstrak - Menerapkan collaborative approaches dalam pelajaran writing telah terbukti membawa banyak manfaat. Namun, sebagian besar penelitian tentang metode collaborative writing dalam pengajaran bahasa selama ini lebih terfokus pada konteks bahasa kedua dibandingkan dengan konteks bahasa asing. Penelitian ini mempelajari persepsi mahasiswa EFL (English as a Foreign Language) Jurusan Bahasa Inggris asal Aceh di Universitas Islam Negeri Ar-Raniry, Banda Aceh, Indonesia, terhadap penerapan metode collaborative writing pada mata kuliah writing mereka. Penelitian ini merupakan sebuah penelitian kualitatif yang menggunakan pendekatan narrative inquiry sebagai instrumen penelitian dan menekankan pada pengalaman belajar peserta didik dengan menggunakan metode collaborative writing. Untuk memahami persepsi peserta didik tentang pembelajaran kolaboratif, peneliti mengamati, mencatat dan merekam setiap tanggapan wawancara mereka. Hasil penelitian ini menunjukkan bahwa penerapan metode collaborative writing dianggap bermanfaat oleh para mahasiswa tidak hanya untuk meningkatkan keakuratan dan kejelasan tulisan mereka, tetapi juga memberikan kesempatan bagi mereka untuk mengumpulkan ide, mengurangi tingkat kegelisahan mereka dalam menulis, dan meningkatkan rasa percayaan diri mereka sebagai penulis. Selain itu, hasil penelitian ini juga menunjukkan bahwa para mahasiswa EFL tersebut meyakini bahwa penerapan collaborative writing dalam menyelesaikan tugas writing mereka tidak selalu berhasil dikarenakan adanya perbedaan gaya penulisan, kemalasan sosial, serta tekanan waktu. Temuan ini dapat berfungsi sebagai sumber rujukan dalam implementasi metode collaborative writing yang lebih efektif. Penelitian ini ditutup dengan rekomendasi untuk kajian pedagogis lebih jauh tentang berbagai aspek collaborative writing dalam konteks EFL.

Key words: persepsi mahasiswa, collaborative writing, mata kuliah writing

\section{INTRODUCTION}

Writing nowadays plays an important role in a person's professional life since it has been regarded as one of the essential skills in business and education. In second or foreign language learning, writing is one of the major requirements in the syllabi of English for academic purposes. However, the ability to write fluently and effectively is the 
most challenging skill to learn for most English language learners. Undoubtedly, writing is a complicated process through which ideas are created and expressed. Learning to write in a foreign language is even harder and it may take a considerable amount of time and effort to do so efficiently. Since composing an accurate and fluent paragraph has been considered as one of the most important communicative skills in English language teaching and is by no means an easy task for EFL learners, English writing instruction plays a quite prominent role in foreign language education (Javadi-Safa, 2018) and thus research on the field of writing has been gaining popularity (Dar \& Khan, 2020; Haider, 2012).

Over time, the interest in a more communicative approach to language teaching has resulted in the growth of pair work in second language contexts (Taylor \& Wigglesworth, 2009). From a pedagogical perspective, pair and small group work has been emphasized for the multiple advantages it confers. Pair work provides language learners with opportunities to interact in collaborative situations, in which two or more learners do activities together in certain tasks. However, in order for a collaborative learning to take place, the learners should be more or less at the same level of proficiency (Biria \& Jafari, 2013), together attempting to build and maintain a shared conception of a problem. It has been said that students can learn best in a more learner-centered, collaborative learning context compared with individualistic and competitive learning settings (Osman et al., 2011). Learners who work collaboratively were able to assist each other to stretch their linguistic abilities (Ibrahim et al., 2015; Sousa et al., 2019; Yavuz \& Arslan, 2018). They participate actively in a collaborative learning context and construct their linguistic knowledge through interacting with other learners.

The underlying premise of collaborative writing is Vygotsky's sociocultural theory (Storch, 2013), which considers learning as a social process and maintains that learning occurs as a result of interaction among humans in social milieu. Nykopp et al. (2019) defined collaborative writing as "a learning task in which students in small groups construct and write a text together" (p. 537). The product of this shared document is commonly referred to as scaffolding. Many researchers have shown that scaffolding occurs in a group work where the role of the expert is shared with other learners. Scaffolding activities in classrooms enable the students to discuss ideas, mechanics, word choice, grammatical form, and by discussing all these elements, they develop a language to talk about writing. The collaborative writing process is thus referred to as a collective scaffolding ( $\mathrm{Li} \&$ Swanson, 2014).
Having its origin from the collaborative learning, collaborative writing has become an important component of a writing classroom, and its importance and benefits have become undeniable. Collaboration allows for productive feedback and critique, increases productivity and saves time, ensures overall writing effectiveness, and accelerates decision-making time (Brown \& Kolin, 2017). Doing tasks through collaborative writing not only helps the students achieve a designated task, but also encourages them to communicate more meaningfully (Storch, 2013). In collaborative writing activities, learners mutually scaffold each other to find how to best express their intended meaning by giving and receiving assistance as they interact with each other while working towards the common task goal. They also contribute by pooling their knowledge and resources for joint decision making and problem solving (Wismath \& Orr, 2015). Also, through collaborative writing, traditional teaching classroom is shifted from teacher-centered into student-centered classroom (Ghufron \& Ermawati, 2018; Zhou et al., 2019). Students take their new role as active learners, while the teacher's plays the role of an expert mentor. The learners are the center of the classroom and the knowledge seekers. They are responsible for their learning, collaborate in achieving certain tasks while tutoring and consulting one another, and learn to work as a team. There is student-student interaction in problem-solving assignment, and thus learning takes place. As a result, student-centered classroom can create a community of learners where they share experiences, support each other and learn from each other. The teacher's roles in a student-centered classroom are to manage collaborative activities, monitor the students' groups, make sure that each group is doing their tasks, create writing assignments, and assess students' work. This change of roles can shift the classroom from traditional way of teaching to more modern teaching style. Learners may be better teachers for their peers. In other words, collaborative writing changes the dynamics of the classroom where the teachers used to be the source of knowledge and the learners are passively receiving the knowledge with little chance to work together. Furthermore, collaboration in ESL writing may foster language accuracy as well as a sense of confidence (Young et al., 2018). However, as precollaborative activities, learners should be made aware of the importance of mutual interactions and taking complementary roles as they plan, generate and exchange ideas and views with their peers. In other words, learners are expected to listen to each other in order to obtain different perspectives and to discover alternative ways of thinking.

Integrating collaborative approaches in ESL writing class allows the students not only to achieve their task collaboratively, but also to have an opportunity to communicate, discuss about the 
writing strategies as well as scaffold one another (Storch, 2011). There are some individual differences among the students. Some of them know more about writing than others. For example, some students cannot write well, but they can suggest good topics. Some others cannot bring up good ideas or examples, but they can write well. Some may be better than others at organization, sentence structure and writing mechanics. Others are better in sense of audience and writing purpose. In this case, collaborative writing gives the students a chance to contribute their strength to others. Learners are different in their language proficiency, background experiences, knowledge and the likes, and by writing collaboratively, they tutor, learn, and transform knowledge from each other (Fung, 2010). Mutual sharing of ideas among the learners and contributing of different writing styles may allow the learners to produce accurate and rich context. Such a pooling of students' different abilities can lead to co-construct knowledge and improve their writing skills more than what they could achieve individually. Khatib \& Meihami (2015) also expands on the benefits of collaborative writing in her writing on collaborative dialogue and language. She defines collaborative dialogue as the talk that emerges when learners engage in a problem-solving activity during collaborative writing. During collaborative writing activities, learners use language in more meaningful way. They try their best to express their intended meaning to their peers. Therefore, not only does collaborative writing have the students collaborate in writing and share knowledge, but they also use their target language to talk about writing which, without any doubt, will help them improve their target language.

A number of studies on collaborative writing have yielded positive findings. Researches conducted in first language L1 and L2 settings have shown that collaborative writing allow the students to foster reflective thinking as they are engaged in group explaining and sharing their ideas to their peers (Ransdell \& Barbier, 2012; Zhang, 2018, 2019). When learners' ideas are challenged by their peers, they will try to convince, defend, and protect their view points or they might need to reconsider their beliefs and ideas. This process will stimulate a deep level of information processing. Studies in L2 contexts have also shown that during the process of collaborative writing, the learners focus not only on the grammatical accuracy and lexical choices, but also on discourse (Lin \& Maarof, 2013; Meihami et al., 2013; Zhang, 2018). In L2 classroom, collaborative writing enables the learners to observe and model their peers' thinking and writing strategies (Supiani, 2017). During collaborative activities, the students are expected to have opportunities to brainstorm, initiate ideas, discuss them, and then start to write collaboratively. Thus, they engage in productive discussions to create new ideas and effective planning. They respond to one another during the writing process, which will help them understand the task at hand. Furthermore, other studies also reported that the students' participation and discussion during collaborative writing activities encourage self-directed learning (SDL) or autonomy (Deveci, 2018; Tanyeli Zeki \& Kuter, 2018), which is crucial for more effective learning.

Although collaborative writing offers many benefits and was reported to be an effective and valuable means for language learning, it comes with some disadvantages as well. Brodahl \& Hansen, (2014) found that collaborative writing can be timeconsuming in some occasions particularly due to the frequent frustrating disagreement on the style of writing among the members of the writing group. As a result, some teachers might find that implementing collaborative writing slows down the students' writing process. Similarly, Lee et al. (2015) pointed out that even though a conflict during collaborative activities "stimulates members' thinking by making them explain, argue, and negotiate their position" (p. 568), some kinds of conflicts or disagreements during collaboration can be so difficult to resolve that collaborators might agree on disagreeing. This, of course, will impede reaching to a consensus and will eliminate all the process of learning. Hewett and Robidoux (2010) also raised the issue of power or authority in the collaborative writing group. In his study on collaborative writing in the workplace, he found that some group members might have a domineering character and impose their opinions which makes others irritated and unwilling to participate. He also noted that unequal division of labor and decrease of the sense of ownership of text will also lead to limited creativity, since the members of the writing group might feel that the text is not for their individual credit.

Nevertheless, despite the popularity of research on collaborative writing, little work has been carried out to investigate students' perceptions on the application of collaborative writing, and previous works have not comprehensively considered its application in EFL contexts. Learners' engagement in a learning activity might be affected by whether they believe that it is likely to facilitate their language learning or not. Therefore, a teacher should take into account students' personal preferences and experiences since they can substantially facilitate the acquisition process. In addition, many analyses and results of the research on L2 writing are largely focused on ESL contexts, and consequently, they are unable to resolve the challenges and issues in EFL settings. Because English language teaching in EFL settings encompasses a broad learning community, the development of any pedagogical frameworks in this field is not complete without proportionate recognition of those settings. Thus, this research 
attempted to fill the gaps in the study of collaborative writing by focusing on the Acehnese EFL students and their perceptions on the application of collaborative writing in their classroom. The findings of this research might provide teachers with evidence regarding the effectiveness of using collaborative writing approach in teaching writing especially in EFL contexts and enable educators or curriculum designers to make informed pedagogical adjustment by establishing appropriate textbooks for effective collaborative approach in EFL writing.

\section{RESEARCH METHODOLOGY}

This qualitative research design used narrative inquiry since the study emphasized on exploring and examining participants learning experience or story sharing (Trahar, 2008). Narrative inquiry was employed as the research instrument to collect students' experiences. The research was conducted at the Department of English Language Education of Ar-Raniry State Islamic Universities, Banda Aceh, Indonesia. The participants were selected by using purposive sampling based on two criteria: their enrollment in three-semester writing courses and their completion of at least two collaborative writing projects or assignments throughout their courses. Among the 67 EFL students who were enrolled in Academic Writing course, all of whom had completed three-semester writing courses, seven (7) students were selected because they met the criteria; they participated continuously for three terms in writing courses with collaborative writing project or assignment. Therefore, these students met the profile as good informants who were rich in information on collaborative learning experience.

The participants completed narrative frames after they had finished their three-semester writing courses, namely Writing I, Writing II and Writing III. Afterwards, semi-structured interview was conducted with the participants in order to reveal their experience, concerns, as well as aspirations identified with their engagement in collaborative writing project or assignment in the past, present, or future. The researcher observed, took notes, recorded, and transcribed the interview verbatim. Then, the data compiled from participants underwent the 'restorying' process, during which definable aspects of the narratives were broken down into themes, reformed and presented in text. Upon this process, two themes became visible: positive perceptions on collaborative writing, and negative perceptions on collaborative writing.

The participants were constantly involved throughout the process of gathering, restorying, and reporting their narratives. The results were also emailed to the participants to be verified in order to make sure the information was accurately presented.

\section{FINDINGS AND DISCUSSION}

\section{Theme I: Students' Positive Perceptions toward Collaborative Writing}

Interviews with the participants following their three-semester writing courses yielded some interesting insights about their feedback to collaborative writing. Six out of the seven participants $(85.71 \%)$ reported positive experience with collaborative writing. Two participants $(28.57 \%)$ reported that they produced better essays when they worked in group as compared to working alone because they could exchange information and ideas with more people. These participants also reported their preference for collaborative writing over individual writing because collaborative writing contributed to not only their writing skills but also their other English language skills. Below are the students' narratives categorized under proper themes.

"If [writing] alone, I stick to one point [of view]. In group, [we] can share [different] points [of view] and ideas. There is a discussion, so we can produce better writing in group" (S1).

"Sometimes, my friends say something when we write together, if I think it's a good idea, I will just write it down. And maybe when I have an idea, but I don't know how to say it, my friend can help me complete my sentence. So, we have more ideas to write and more help. Together we can find better ideas to use. When we write together, we stop sometimes and think about good ideas. Then, we share the ideas. When my friends in group give me ideas and information, I will think about them first before I write them down. If they are good, we write them down" (S2).

The above comments showed that the participants found their collaborative writing experience positive, reporting that it gave them an opportunity to share and learn different ways of expressing their ideas in writing from each other. They reported that they could produce better essays by pooling ideas together, so they were more satisfied with their work. According to Storch (2013), such pooling of resources allowed learners to observe, share ideas, and allows them to improve their ideas by learning from each other.

Two other participants $(28.57 \%)$ also reported that they were able to organize their essay more effectively when they wrote collaboratively: 
"When I wrote alone, I wasn't thinking of the steps...my ideas were not organized very well. But when I work with my friends, I talk about my ideas with them and sometimes they say, "This one should go first and this one should go at the end." My friends always suggest that we should do it like this or like that" (S4).

"My writing is not good. When I write my homework alone, it often confuses me what I need to write in the introduction and what I need to write in the conclusion because they look the same. And when I write with my friends, I think they know and they always say we should write these ideas in the first paragraph and these ideas in the last paragraph" (S5).

Collaborative writing was seen as positive by the participants because of the influence it had on their essay organization. The students reported that they wrote more effectively in pairs, small groups, and teams as compared to when working alone. Similarly, Shehadeh (2011) in her research on the effectiveness of collaborative work revealed that collaborative writing had a significant effect on L2 learners' essay content and organization.

The other two participants (28.57\%) reported similar positive attitudes towards collaborative writing and they found it helpful to learn from each other. Two students reported that they learned new ways of writing as well as new vocabulary words from their peers while writing with their group members:

"My problem when I write [is that] I don't know how to connect the sentences together. My paragraph is not good enough because my sentences are not well-connected. When we write the essay together, I give my friends sentences, and he connect them together. He always said to me I must connect the sentences together to make them smooth and to make the writing look good" (S6).

"I always wrote alone and I thought I knew a lot of vocabulary in English, but when I wrote with my friends, it turned out I didn't know many words. They knew more than me. Every time we write together, they always give me new words I don't know. I like to write with my friends" (S7).

The participants believed that pooling their ideas and resources with a partner not only helped them produce a better writing product, but also allowed them the opportunity to become more aware of their own English writing abilities. The participants' positive narratives suggest that during collaborative writing, they not only accomplished the goal of finishing the essay, but also learned from and facilitated each other during the process. This finding demonstrates that collaborative pair work creates learning environments where learners provide contingent scaffolding to each other, This finding is in line with the previous research findings by Such (2019), who found that in mutually scaffolding each other, students showed efforts at achieving on one common task. aligned with Vygotsky's sociocultural theory of learning, cognitive and linguistic development takes place during learners' scaffolding interaction, enabling them to produce new language or ideas that would normally be beyond their competencies (Caruso, 2014).

Three participants $(42.85 \%)$ also reported receiving at least one help from other group members when they worked together. They narrated as follows:

"I like writing with my classmates because they helped me. We discuss about anything we want to write. I like the discussion because every time we discuss I learn something that I don't know, and in discussion we bring new ideas and examples to write in our essay" (S1).

"I think my friends know more grammar and words in English than me. Sometimes when we were writing, I gave them one word and they said we should use another word because it was better. I think they were right. They always bring good words and we use them in our writing. And I am happy because we always get good scores from the teacher. Also, I learn [new] words from my friends, and I will use them next time I write" (S2).

"I think I have two friends in my group who are weak in writing. I always teach them when we write the essay, but they are good in brainstorming. They always suggest good ideas to use in our writing, and I provide the reasons and examples to support their ideas. I think we worked well together. I give them the help they need and they helped me too" (S3).

The responses indicated that the participants found discussion during collaborative writing helpful. Not only did they learn from each other such basic elements of writing as word choice and expressions, but they learned the micro and macro aspects of writing from each other. In other words, they also compensated each other for what they lacked. Similarly, the other participants $(57.14 \%)$ narrated:

"I learned from my friends how to build sentences when we wrote together. I watched how my friends write sentences and support them with examples. They taught me that I had to write examples or reasons for ideas and support ideas with examples. We did that together in group and I didn't know how to write like that before" (S4). 
"I learned new ways in writing every essay. My friends told me how to write thesis statement in the first paragraph, how to make conclusion or summarize an essay, and also how many ideas I should write in an essay" (S5).

"I learn from my friends in my group I must use different and not repeat same words again and again. I see how my friends change words, use different words that have same meaning, different ideas, different examples, and supporting ideas" (S6).

"My friends in my group gave me good ideas, and they asked me how write these ideas in sentences. I teach them how to organize the essay and how to write their ideas in good sentences. I tell them each paragraph should have one idea and supporting sentences. Like examples and facts. I think we are good team and we write good essay with good ideas" (S7).

The participants responded that they were exposed to many new ideas through the group discussion. It is obvious that the members learned different styles of writing from one another. They also learned how to construct sentences, generate, support, and organize their ideas. The participants benefited from the writing strengths of their writing partners as they served as a source of knowledge for one another. Hence, the collaboration triggered cognitive and critical thinking. New ideas either helped the members to learn different perspectives of thinking or triggered their cognitive processes to evaluate the appropriateness of the ideas. This experience resulted in learning and knowledgebuilding in idea generation, which they later applied in their individual writing. As a result, writing produced by collaborative writing is superior in terms of grammatical accuracy and linguistic complexity (Villarreal \& Gil-Sarratea, 2019). In fact, according to de Oliveira \& Smith (2019), when learners were assisted by a more capable partners, they were able to produce more target language. In other words, when L2 learners interact in pairs or groups with more competent peers, they were able to use target language beyond their individual competences (Davey Chesters, 2012).

Furthermore, two participants (28.57\%) commented on the role collaborative writing played in reducing their apprehension:

"Writing with my friends helps me and makes me feel less worried because I always feel worried when I have homework and have to do it alone at home. Every time I write I'm worried that it is incorrect. But when I work with my friends, I feel better because I am not alone. I ask my friends [for help] and I meet them and we all write in one paper. I'm not afraid, and I want to write more with my friends" (S4).

"I always change my mind and my opinion when I write, so I waste much time. That's why I don't like it when I have a writing homework. But I like working with my friends. When I change my mind, they say, 'No, it is good,' and we write it down and we write more sentences" (S4).

Based on their responses, both students perceived that collaborative writing activities helped them reduce their writing apprehension. They felt at ease and more comfortable with writing in group because it makes them less hesitant about their own writing. Collaborative writing gave confidence, especially to those lower-level studentwriters who still lack self-confidence. In this regard, Aminloo (2013) stated that collaborative work gave even the most reserved or reluctant student enough security to participate more frequently. Similarly, this finding also echoed the results of past research by Shehadeh (2011) and Lin and Maarof (2013) who proposed that collaboration boosted learners' self-confidence.

\section{Theme II: Students' Negative Perceptions toward Collaborative Writing}

Despite the strong reasons for implementing collaborative writing task in L2 writing classroom, collaborative writing does not always succeed. Three participants $(42.85 \%)$ also identified their negative perception and experiences in writing collaboratively at individual and group levels. One of them reported their partners' resistance to invest their time and effort that a group project required:

"My friends didn't give me ideas to write about. They didn't help me a lot, maybe because they thought I was better than them in writing. When I asked them questions about the topic we were writing, they said they didn't know. This is why I prefer to work with partners of my own choice" (S5).

In collaborative writing, there is a tendency for a group member to stay in the background and contributing almost nothing to the group, but frequently still taking credit for the outcome. This unwillingness to commit themselves to full participation might upset the rest of the group affected the collaboration. Surely, there are a number of reasons causing a member in a group to assume passive role in the group (he or she might be shy or reserved and feel awkward working with others, or he or she may feel not as skilled as the rest of the group as narrated above), but such behavior such as passivity, irresponsibility, and unreliability can have an adverse effect on learning.

Often, when a collaborative writing task is 
given in class, a few learners will see this as free time from their teacher. These "free-riders", as Storch (2013, p.161) called them, show little to no effort or commitment to the group. According to Arnold et al. (2012), this so-called social loafing will undoubtedly occur in collaborative classroom. Some learners use this opportunity to talk about unessential subjects and not concentrate on the current work. Quite possibly, too many free-riders might drive productive learners to cut down their endeavors and commitments (Joyce, 1999).

Working with unfamiliar partners, one participant narrated:

"Sometimes, in our group we have some problems because we don't know each other well. It's our first time to be in a group together. We don't want to offend each other, so I always agree with what they say. However, if I work with my close friends, I will discuss with them" (S6).

The participant reported her unwillingness to voice out her opinion for fear of offending others. She would remain silent even if they agreed with other members' ideas since she did not want to get into arguments and hurt their feelings. She also believed that if she had worked with close friends, she would have expressed her opposing views openly. This case is quite prevalent among Asian ESL/EFL learners, who view writing as an individual assignment and, owing to their collectivist culture, would rather accept the dominant members' ideas than criticizing them for fear of upsetting the group and being offensive (Le et al., 2018). This issue, however, can be solved by equally sharing the tasks among group members.

The other participant reported time constraint as a problem during her collaborative experience:

"My writing in group with my friends went well, but I think the teacher did not give us enough time to finish the essay. It was very difficult to do many things in short time. We needed more time to think about ideas and proofread" (Student 7).

The participant believed the allocated time was not sufficient to go through the writing process, to have enough discussion, and to complete the task. They would like to have more time for their collaborative writing. This result is supported by (Felipeto, 2019), who found that collaborative writers required more time to complete their writing task than individual writers, even though the former's products are linguistically better. In order to cope with this problem, Ajideh et al. (2016) proposed that teachers provide ample, but not too much, time for learners to complete their tasks since most of them are not familiar with collaborative writing requirements.

\section{CONCLUSION}

This study showed that the Acehnese EFL learners were relatively satisfied with their collaborative writing, reporting such benefits such as pooling of resources, better essay content and organization, mutual scaffolding, improved grammatical accuracy and linguistic complexity, reduced apprehension, and higher self-confidence. However, some arguments that collaborative writing may not always be feasible were also proposed by the learners, including overreliance on others, social loafing, and time-management problems. From an educational perspective, the results of this study give complementary supplementary empirical evidence of the benefits of collaborative writing in EFL writing class.

This study had some limitations, one of which was related to its relatively small sample size. Future studies could increase this sample size by including more EFL learners in order to not only raise the generalizability of the results, but also decrease any potential of researcher bias. Future research could also investigate teachers' collaborative writing perception and experiences so as to increase our understanding of their dissatisfaction in such teaching situations.

\section{REFERENCES}

Ajideh, P., Leitner, G., \& Yasin Yazdi-Amirkhiz, S. (2016). The Influence of Collaboration on Individual Writing Quality: The Case of Iranian vs. Malaysian College Students*. Journal of English Language Teaching and Learning, 17(17), 1-24. https://elt.tabrizu.ac.ir/article_4958.html

Aminloo, M. S. (2013). The Effect of Collaborative Writing on EFL Learners Writing Ability at Elementary Level. Journal of Language Teaching and Research, 4(4). https://doi.org/10.4304/jltr.4.4.801-806

Arnold, N., Ducate, L., \& Kost, C. (2012). Collaboration or cooperation? Analyzing group dynamics and revision processes in wikis. CALICO Journal, 29(3), 431-448. https://doi.org/10.11139/cj.29.3.431-448

Biria, R., \& Jafari, S. (2013). The Impact of Collaborative Writing on the Writing Fluency of Iranian EFL Learners. Journal of Language Teaching and Research, 4(1). https://doi.org/10.4304/jltr.4.1.164-175

Brodahl, C., \& Hansen, N. K. (2014). Education students' use of collaborative writing tools in collectively reflective essay papers. Journal of 
Information Technology Education:Research, 13(1), 91-120. https://doi.org/10.28945/1960

Brown, D. H., \& Kolin, P. C. (2017). Successful Writing at Work. In The South Central Bulletin (Vol. 42, Issue 3) https://doi.org/10.2307/3187973

Caruso, G. (2014). The Impact of Wiki-based Collaborative Writing on English L2 Learners' Individual Writing Development. ProQuest Dissertations and Theses, 188. https://doi.org/10.13140/2.1.1618.4647

Dar, M. F., \& Khan, I. (2020). Writing Anxiety Among Public And Private Sectors Pakistani Undergraduate University Students. Pakistan Journal of Gender Studies, 10(1). https://doi.org/10.46568/pjgs.v10i1.232

Davey Chesters, S. (2012). The Socratic classroom: Reflective thinking through collaborative inquiry. In The Socratic Classroom: Reflective Thinking Through Collaborative Inquiry. Sense Publishers. https://doi.org/10.1007/97894-6091-855-1

de Oliveira, L. C., \& Smith, B. E. (2019). Expanding Literacy Practices Across Multiple Modes and Languages for Multilingual Students. Information Age Publishing, Inc.

Deveci, T. (2018). Student perceptions on collaborative writing in a project-based course. Universal Journal of Educational Research, 6(4), 721-732. https://doi.org/10.13189/ujer.2018.060415

Felipeto, S. C. S. (2019). COLLABORATIVE AND INDIVIDUAL WRITING IN A CLASSROOM: AN ANALYSIS OF TEXTS WRITTEN BY ELEMENTARY SCHOOL STUDENTS. Alfa: Revista de Ling\&uuml;\&iacute;Stica, 63(1), 141-161. https://go.gale.com/ps/i.do?p=AONE\&sw=w \&issn $=00025216 \& v=2.1 \& i t=r \& i d=$ GALE $\% 7$ CA592138556\&sid=googleScholar\&linkacces $\mathrm{s}=$ fulltext

Fung, Y. M. (2010). Collaborative writing features. RELC Journal, 41(1), 18-30. https://doi.org/10.1177/0033688210362610

Ghufron, M. A., \& Ermawati, S. (2018). The strengths and weaknesses of cooperative learning and problem-based learning in EFL writing class: Teachers and students' perspectives. International Journal of Instruction, 11(4), 657-672. https://doi.org/10.12973/iji.2018.11441a

Haider, G. (2012). An Insight Into Difficulties Faced
By Pakistani Student Writers: Implications for Teaching of Writing. Journal of Educational and Social Research, 2(3), 17-28. https://doi.org/10.5901/jesr.2012.v2n3p17

Hewett, B. L., \& Robidoux, C. (2010). Virtual collaborative writing in the workplace: Computer-mediated communication technologies and processes. In Virtual Collaborative Writing in the Workplace: Computer-Mediated Communication Technologies and Processes. IGI Global. https://doi.org/10.4018/978-1-60566-994-6

Ibrahim, N., Shak, M. S. Y., Mohd, T., Ismail, N. A., Perumal, P. D. a/p, Zaidi, A., \& Yasin, S. M. A. (2015). The Importance of Implementing Collaborative Learning in the English as a Second Language (ESL) Classroom in Malaysia. Procedia Economics and Finance, 31, 346-353. https://doi.org/10.1016/s22125671(15)01208-3

Javadi-Safa, A. (2018). A Brief Overview of Key Issues in Second Language Writing Teaching and Research. International Journal of Education and Literacy Studies, 6(2), 12. https://doi.org/10.7575/aiac.ijels.v.6n.2p.15

Joyce, W. B. (1999). On the Free-Rider Problem in Cooperative Learning. Journal of Education for Business, 74(5), 271-274. https://doi.org/10.1080/08832329909601696

Khatib, M., \& Meihami, H. (2015). Languaging and Writing Skill: The Effect of Collaborative Writing on EFL Students' Writing Performance. Australian International Academic Centre, 6(1), 2203-4714. https://doi.org/10.7575/aiac.alls.v.6n.1p.203

Le, H., Janssen, J., \& Wubbels, T. (2018). Collaborative learning practices: teacher and student perceived obstacles to effective student collaboration. Cambridge Journal of Education, $\quad 48(1)$, 103-122. https://doi.org/10.1080/0305764X.2016.12593 89

Lee, D., Huh, Y., \& Reigeluth, C. M. (2015). Collaboration, intragroup conflict, and social skills in project-based learning. Instructional Science, 43(5), 561-590. https://doi.org/10.1007/s11251-015-9348-7

Li, S., \& Swanson, P. B. (2014). Engaging language learners through technology integration: Theory, applications, and outcomes. Engaging Language Learners through Technology Integration: Theory, Applications, and Outcomes, 1-368. https://doi.org/10.4018/978- 
$1-4666-6174-5$

Lin, O. P., \& Maarof, N. (2013). Collaborative Writing in Summary Writing: Student Perceptions and Problems. Procedia - Social and Behavioral Sciences, 90, 599-606. https://doi.org/10.1016/j.sbspro.2013.07.131

Meihami, H., Meihami, B., \& Varmaghani, Z. (2013). The Effect of Collaborative Writing on EFL Students' Grammatical Accuracy. International Letters of Social and Humanistic Sciences, $11, \quad 47-56$. https://doi.org/10.18052/www.scipress.com/ils hs. 11.47

Nykopp, M., Marttunen, M., \& Erkens, G. (2019). Coordinating collaborative writing in an online environment. Journal of Computing in Higher Education, 31(3), 536-556. https://doi.org/10.1007/s12528-018-9203-3

Osman, G., Duffy, T. M., Chang, J. yu, \& Lee, J. (2011). Learning through collaboration: Student perspectives. Asia Pacific Education Review, 12(4), 547-558. https://doi.org/10.1007/s12564-011-9156-y

Ransdell, S., \& Barbier, M.-L. (2012). New Directions For Research In L2 Writing. Kluwer Academic Publishers. https://doi.org/10.1007/978-94-010-0363-6_1

Shehadeh, A. (2011). Effects and student perceptions of collaborative writing in L2. Journal of Second Language Writing, 20(4), 286-305.

https://doi.org/10.1016/j.jslw.2011.05.010

Sousa, L. P. de Q., Tiraboschi, F. F., Lago, N. A. do, \& Figueiredo, F. J. Q. de. (2019). COLLABORATIVE ENGLISH LANGUAGE LEARNING: SOME REFLECTIONS FROM INTERACTIONS BETWEEN PAIRS. Trabalhos Em Linguística Aplicada, 58(1), 259-286.

https://doi.org/10.1590/010318138653439430 941

Storch, N. (2011). Collaborative writing in L2 contexts: Processes, outcomes, and future directions. Annual Review of Applied Linguistics, 31, 275-288. https://doi.org/10.1017/S0267190511000079

Storch, N. (2013). Collaborative Writing in L2 classrooms. Channel View Publications.

Such, B. (2019). Scaffolding English language learners for online collaborative writing activities. Interactive Learning Environments. https://doi.org/10.1080/10494820.2019.15792
33

Supiani, S. (2017). TEACHING WRITING SKILL THROUGH COLLABORATIVE WRITING TECHNIQUE: FROM THEORY TO PRACTICE. JEELS (Journal of English Education and Linguistics Studies), 4(1), 3752. https://doi.org/10.30762/jeels.v4i1.330

Tanyeli Zeki, N., \& Kuter, S. (2018). Impact of collaborative and reflective writing activities on students' autonomy in writing. Quality and Quantity, 52(1), 343-360. https://doi.org/10.1007/s11135-017-0615-3

Taylor, L., \& Wigglesworth, G. (2009). Are two heads better than one? Pair work in L2 assessment contexts. Language Testing, 26(3), 325-339.

https://doi.org/10.1177/0265532209104665

Trahar, S. (2008). Using narrative inquiry as a research method: an introduction to using critical event narrative analysis in research on learning and teaching, by Leonard Webster, and Patricie Mertova. Compare: A Journal of Comparative and International Education, 38(3), 367-368. https://doi.org/10.1080/03057920802112933

Villarreal, I., \& Gil-Sarratea, N. (2019). The effect of collaborative writing in an EFL secondary setting. Language Teaching Research. https://doi.org/10.1177/1362168819829017

Wismath, S. L., \& Orr, D. (2015). Collaborative Learning in Problem Solving: A Case Study in Metacognitive Learning. The Canadian Journal for the Scholarship of Teaching and Learning, 6(3). https://doi.org/10.5206/cjsotlrcacea.2015.3.10

Yavuz, O., \& Arslan, A. (2018). Cooperative learning in acquisition of the english language skills. European Journal of Educational Research, 7(3), 591-600. https://doi.org/10.12973/eu-jer.7.3.591

Young, N. D., Noonan, B. T., \& BonannoSotiropoulos, K. (2018). Wrestling with Writing: Instructional Strategies for Struggling Students. Rowman \& Littlefield.

Zhang, M. (2018). Collaborative writing in the EFL classroom: The effects of L1 and L2 use. System, 76, 1-12. https://doi.org/10.1016/j.system.2018.04.009

Zhang, M. (2019). Understanding L1 and L2 interaction in collaborative writing: A lexicogrammatical analysis. Language Teaching Research. 
https://doi.org/10.1177/1362168819859911

Zhou, X., Chen, L.-H., \& Chen, C.-L. (2019). Collaborative Learning by Teaching: A
Pedagogy between Learner-Centered and Learner-Driven. Sustainability, 11(4), 1174. https://doi.org/10.3390/su11041174 